combined aqueous layers were extracted with $100 \mathrm{~mL}$ of ether and then acidified with concentrated $\mathrm{HCl}$ and extracted with dichloromethane $(3 \times 75 \mathrm{~mL})$. The combined organic extracts were washed with $100 \mathrm{~mL}$ of brine and dried $\left(\mathrm{MgSO}_{4}\right)$. Removal of solvent gave $4.38 \mathrm{~g}(59.6 \%)$ of 11 as a yellow solid. Recrystallization from ether yielded material with $\mathrm{mp} 136.5-137.5^{\circ} \mathrm{C}$ (lit. ${ }^{11} \mathrm{mp} 136-137^{\circ} \mathrm{C}$ ).

Acknowledgment. The author thanks Michael G. Legendre for providing the mass spectra and Ingenue' Cobbinah, Angela Haynes, Jacki Novak, Mary P. Lovisa, Jan Ferrara, and James Philips for technical assistance.

\title{
[3 + 2]- and [5 + 2]-Cycloadditions of the Cyclohepta-2,4-dienyl Cation
}

\author{
Werner Heilmann, Rainer Koschinsky, and Herbert Mayr*
}

Institut für Chemie der Medizinischen Universität zu Lübeck, D-2400 Lübeck 1, Federal Republic of Germany

Received October 14, 1986

\begin{abstract}
The cyclohepta-2,4-dienyl cation (9), generated in situ from 5-chloro-1,3-cycloheptadiene (10) and zinc chloride, undergoes a [3 + 2]-cycloaddition with 1-phenylpropyne (11) to give the bicyclo[4.2.1]nona-2,7-dien-9-yl cation (18), which is stereoselectively trapped by a chloride ion. The corresponding reaction of 10 with 1-methoxy2 -methylpropene (13) yields the aldehyde 14 and the bicyclo[3.2.2] nonenes 15a-c and 16, which are rationalized by a stepwise [ $5+2]$-cycloaddition process. Configurations and conformations of the bicyclo[3.2.2]nonenes are investigated by NMR spectroscopy.
\end{abstract}

The thermally allowed $\left[\pi_{8}+{ }_{\pi}{ }^{2}\right]$-cycloaddition reactions $^{1}$ can be realized in four different ways (eq 1-4).

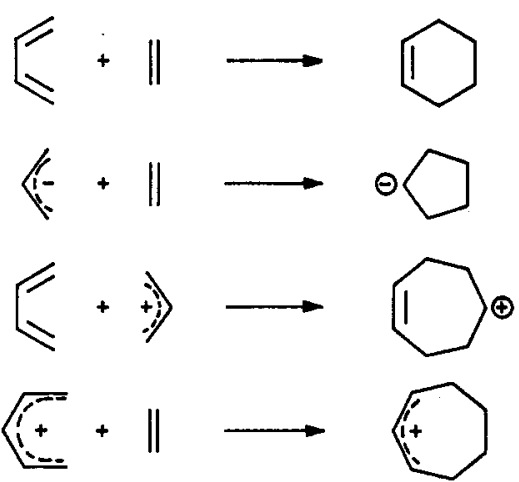

Synthetic as well as mechanistic aspects of Diels-Alder reactions (eq 1$)^{2,3}$ allyl anion, ${ }^{4}$ azallyl anion, ${ }^{4}$ and 1,3-dipolar cycloadditions ${ }^{3,5}$ (eq 2) have been studied in great detail. Allyl cation cycloadditions with 1,3-dienes (eq 3) offer a synthetic access to seven-membered ring compounds, but the mechanism of these reactions is still questionable. $^{6}$ As shown in the following discussion, examples of eq 4 are rare.

(1) Woodward, R. B.; Hoffmann, R. Angew Chem. 1969, 81, 797. Angew. Chem., Int. Ed. Engl. 1969, 8, 781.

(2) (a) Wasserman, A. Diels Alder Reactions; Elsevier: New York, 1965. (b) Sauer, J. Angew. Chem. 1966, 78, 233; 1967, 79, 76. Angew. Chem., Int. Ed. Engl. 1966, 5, 211; 1967, 6, 16. (c) Sauer, J.; Sustmann, R. Angew. Chem. 1980, 92, 773. Angew. Chem., Int. Ed. Engl. 1980, 19, 779.

(3) Desimoni, G.; Tacconi, G.; Barco, A.; Pollini, G. P. Natural Products Synthesis through Pericyclic Reactions; ACS Monograph 180; American Chemical Society: Washington, DC, 1983.

(4) (a) Kauffmann, T. Angew. Chem. 1974, 86, 715. Angew Chem., Intg. Ed. Engl. 1974, 13, 627. (b) Kauffmann, T. Top. Curr. Chem. 1980, 92,109 .

(5) (a) Huisgen, R. Angew. Chem. 1963, 75, 604; 1963, 75, 742. (b) Padwa, A., Ed. 1,3-Dipolar Cycloaddition Chemistry; Wiley: New York, 1984; Vol I and II.

(6) (a) Hoffmann, H. M. R. Angew. Chem. 1973, 85, 877. Angew. Chem., Int. Ed. Engl. 1973, 12, 819. (b) Hoffmann, H. M. R. Angew. Chem. 1984, 96, 29. Angew. Chem., Int. Ed. Engl. 1984, 23, 1.
Woodward and Hoffmann ${ }^{1}$ cited the perezon pipitzole rearrangement (eq 5$)^{7 \mathrm{a}}$ as the only representative of reaction 4. Deuterium labeling studies provided arguments<smiles>CCCC(C)=C1C(=O)C=C(C)C(=O)C1=C(C)C</smiles>

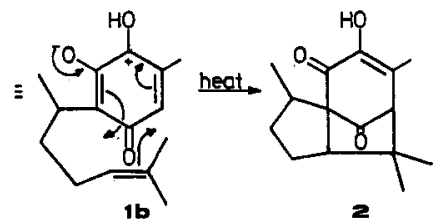

for the concerted nature of this reaction ${ }^{7 b}$ and proved that the rearrangement proceeds stepwise in the presence of a Lewis acid. ${ }^{7 c}$ Intermolecular analogues of this transformation, e.g., the reaction sequence $3 \rightarrow 4,{ }^{8 d}$ have been carried out with 2 -alkoxybenzoquinone derivatives ${ }^{8}$ and 3-hydroxy-4-pyrones. ${ }^{9,10}$<smiles>CCCC1=CC(OC)(OC)C(OC)=CC1=O</smiles>

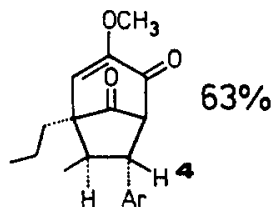<smiles>[CH][InH]</smiles><smiles>[Te]c1ccc2c(c1)OCO2</smiles><smiles>C1CCCCC1</smiles><smiles></smiles>
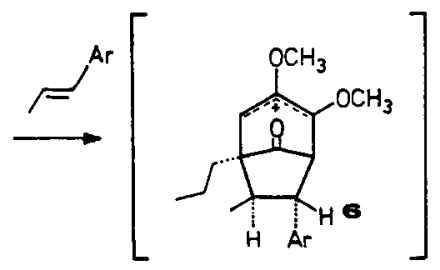

(7) (a) Walls, F.; Padilla, J.; Joseph-Nathan, P.; Giral, F.; Romo, J. Tetrahedron Lett. 1965, 1577. (b) Joseph-Nathan, P.; Mendoza, V.; Garcia, E. Tetrahedron 1977, 33, 1573. (c) Sanchez, I. H.; Yañez, R.; Enriquez, R.; Joseph-Nathan, P. J. Org. Chem. 1981, 46, 2818.

(8) (a) Büchi, G.; Mak, C.-P. J. Am. Chem. Soc. 1977, 99, 8073. (b) Büchi, G.; Chu, P.-S. J. Org. Chem. 1978, 43, 3717. (c) Büchi, G.; Chu, P. S. J. Am. Chem. Soc. 1979, 101, 6767. (d) Mak, C.-P.; Büchi, G. J. Org. Chem. 1981, 46, 1. 
Like 1 and 5, tropylium ions 7 do not incorporate an isolated dienyl cation fragment, and their cycloaddition reactions with alkenes ${ }^{11}$ may alternatively be attributed to class (1) or (4). As an extension of our work on allyl ${ }^{12}$ and allenyl cation ${ }^{13}$ cycloadditions, we have been searching for a clear-cut example of eq $4,[5+2]$-cycloadditions of

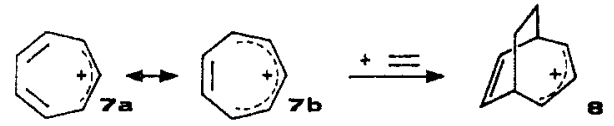

type (4) require U-shaped 2,4-dienyl cations. Acyclic systems, which are forced into U-shape by substituents, are expected to undergo electrocyclic pentadienyl $\rightarrow \mathrm{cy}$ clopentenyl cation ring-closure reactions ${ }^{1,14}$ rapidly. Since the same process may take place in cyclic systems with ring size $\geq 8$, only six- and seven-membered rings remain. The 2,4-cycloheptadienyl cation 9 was finally selected for our studies, as six-membered ring cations that do not possess special structural features like 1 and 5 will aromatize under ordinary reaction conditions.

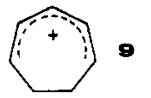

Previously, we have reported that the cycloheptadienyl cation 9 reacts with isobutene and silyl enol ethers with formation of a single new $\sigma$-bond, i.e., normal additions, not cycloadditions, take place. ${ }^{15}$ We have now obtained bicyclic products when the cycloheptadienyl chloride 10 was reacted with 1-phenylpropyne (11) or the enol ether 13 in the presence of $\mathrm{ZnCl}_{2}$ at $-78^{\circ} \mathrm{C}$.

Reaction Products and Structural Assignments. ${ }^{16}$ The zinc chloride/ether-catalyzed reaction of 10 with 11 gave $42 \%$ of the $1: 1$ products $12 \mathbf{a}$ and $12 \mathbf{b}(\approx 10: 1)$. Independent of the way in which the reactants were combined, the yield of $12 \mathbf{a}, \mathbf{b}$ was around $40 \%$ while the remainder were high molecular weight compounds.

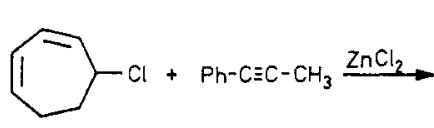

10

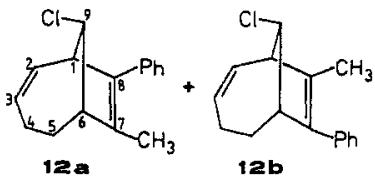

$12 b$
The bicyclo[4.2.1]nonadiene structure of 12a was derived from ${ }^{1} \mathrm{H}$ NMR homonuclear spin-decoupling experiments,

(9) Volkmann, R. A.; Weeks, P. D.; Kuhla, D. E.; Whipple, E. B.; Chmurny, G. N. J. Org. Chem. 1977, 42, 3976.

(10) For other related intramolecular cycloadditions see: (a) Hienuki, Y.; Tsuji, T.; Nishida, S. Tetrahedron Lett. 1981, 22, 867. (b) Ishibashi, M.: Tsuyuki, T.; Takahashi, T. Tetrahedron Lett. 1983, 24, 4843.

(11) (a) Ito, S.; Itoh, I. Tetrahedron Lett. 1971, 2969. (b) Ito, S.; Mori, A.; Saito, I.; Saken, K.; Ishiyama, H.; Sasaki, K. Tetrahedron Lett. 1973 2737. (c) Ito, S.; Itoh, I. Saito, I.; Mori, A. Tetrahedron Lett. 1974, 3887.

(12) (a) Klein, H.; Mayr, H. Angew. Chem. 1981, 93, 1069. Angew. Chem., Int. Ed. Engl. 1981, 20, 1027. (b) Klein, H.; Freyberger, G.; Mayr, H. Angew. Chem. 1983, 95, 62. Angew. Chem., Int. Ed. Engl. 1983, 22, 49. (c) Mayr, H.; Klein, H.; Kolberg, G. Chem. Ber. 1984, 117, 2555.

(13) (a) Mayr, H.; Halberstadt, I. K. Angew. Chem. 1980, 92, 840. Angew. Chem., Int. Ed. Engl. 1980, 19, 814. (b) Mayr, H.; Seitz, B. Halberstadt-Kausch, I. K. J. Org. Chem. 1981, 46, 1041. (c) Mayr, H. Halberstadt-Kausch, I. K. Chem. Ber. 1982, 115, 3479. (d) Mayr, H.; Schütz, F.; Halberstadt-Kausch, I. K. Chem. Ber. 1982, 115, 3516. (e) Mayr, H.; Klein, H. Chem. Ber. 1982, 115, 3528. (f) Mayr, H.; Bäuml, E. Tetrahedron Lett. 1984, 25, 1127. (g) Bäuml, E.; Mayr, H. Chem. Ber $1985,118,694$.

(14) (a) Sorensen, T. S. In Carbonium Ions; Olah, G. A., Schleyer, P v. R., Eds.; Wiley: New York, 1970; Vol. II, Chapter 19. (b) Sorensen, T. S.; Rauk, A. In Pericyclic Reactions; Marchand, A. P., Lehr, R. E., Eds.; Academic: New York, 1977; Vol. II, Chapter 1.

(15) (a) Mayr, H.; Heilmann, W. Tetrahedron 1986, 24, 6657. (b) Mayr, H.; Heilmann, W.; Lammers, R. Tetrahedron 1986, 24, 6663.

(16) The NMR techniques used in this work have been reviewed by: Benn, R.; Günther, H. Angew. Chem. 1983, 95, 381. Angew. Chem., Int Ed. Engl. 1983, 22, 390.
Table I. ${ }^{13} \mathrm{C}$ NMR Chemical Shifts and ${ }^{13} \mathrm{C}-{ }^{13} \mathrm{C}$ Coupling Constants $( \pm 0.25 \mathrm{~Hz}$, in Parentheses) of the Bicyclo[3.2.2]nonenes 15a-c and 16

\begin{tabular}{|c|c|c|c|c|}
\hline & $15 a$ & $15 b$ & $15 \mathrm{c}$ & $16^{a}$ \\
\hline 1 & $\begin{array}{c}43.81 \\
(39.8,32.0)\end{array}$ & $\begin{array}{c}41.05 \\
(39.6,38.0 \\
31.1)\end{array}$ & $\begin{array}{c}41.22 \\
(39.5,38.3,32.2)\end{array}$ & $\begin{array}{c}35.13 \\
(38.8,35.8,31.2)\end{array}$ \\
\hline 2 & $\begin{array}{l}134.50 \\
(39.9)\end{array}$ & $\begin{array}{l}138.16 \\
(39.6)\end{array}$ & $\begin{array}{l}136.94 \\
(39.6)\end{array}$ & $\begin{array}{l}134.26 \\
(38.4)\end{array}$ \\
\hline 3 & $\begin{array}{l}129.95 \\
(43.6)\end{array}$ & $\begin{array}{l}128.19 \\
(43.9)\end{array}$ & $\begin{array}{l}129.44 \\
(43.3)\end{array}$ & $\begin{array}{l}130.66 \\
(42.3)\end{array}$ \\
\hline 4 & $\begin{array}{c}63.77 \\
(43.6,34.2)\end{array}$ & $\begin{array}{c}65.23 \\
(44.1,33.9)\end{array}$ & $\begin{array}{c}66.61 \\
(43.5,33.0)\end{array}$ & $\begin{array}{c}66.00 \\
(43.4,34.4)\end{array}$ \\
\hline 5 & $\begin{array}{c}41.71 \\
(34.7,34.0)\end{array}$ & $\begin{array}{c}42.20 \\
(35.2,34.3)\end{array}$ & $\begin{array}{c}43.59 \\
(37.7,32.8,31.7)\end{array}$ & $\begin{array}{c}48.53 \\
(33.7,32.5)\end{array}$ \\
\hline 6 & $\begin{array}{c}86.89 \\
(37.6,34.7)\end{array}$ & $\begin{array}{c}86.26 \\
(38.5,35.3)\end{array}$ & $\begin{array}{l}82.33 \\
(38.0)\end{array}$ & $\begin{array}{c}36.80 \\
(36.1,35.1,33.9)\end{array}$ \\
\hline 7 & $\begin{array}{c}39.71 \\
(37.6,35.7 \\
32.0)\end{array}$ & $\begin{array}{c}38.28 \\
(38.8,38.2 \\
37.1)\end{array}$ & $\begin{array}{c}40.62 \\
(38.3,36.7)\end{array}$ & $\begin{array}{l}87.52 \\
(36.4)\end{array}$ \\
\hline 8 & $\begin{array}{c}23.62 \\
(34.4,32.0)\end{array}$ & $\begin{array}{c}25.96 \\
(33.4,31.0)\end{array}$ & $\begin{array}{c}25.93 \\
(33.2,32.3)\end{array}$ & 21.26 \\
\hline 9 & $\begin{array}{l}19.68 \\
(34.4)\end{array}$ & $\begin{array}{c}15.78 \\
(34.5,33.3)\end{array}$ & $\begin{array}{c}19.64 \\
(33.2,31.5)\end{array}$ & $\begin{array}{l}17.70 \\
(31.7)\end{array}$ \\
\hline 10 & $\begin{array}{l}23.62 \\
(35.8)\end{array}$ & $\begin{array}{l}30.90 \\
36.7)\end{array}$ & $\begin{array}{l}29.95 \\
(36.6)\end{array}$ & 30.30 \\
\hline 11 & $\begin{array}{l}30.99 \\
(35.6)\end{array}$ & $\begin{array}{l}23.22 \\
(37.1)\end{array}$ & $\begin{array}{l}22.88 \\
(36.3)\end{array}$ & 25.12 \\
\hline 12 & 58.57 & 58.29 & 57.58 & 58.16 \\
\hline
\end{tabular}

${ }^{a}$ Accuracy of $J$ for this compound $\pm 0.5 \mathrm{~Hz}$

which showed that the triplet splitting $(J=6.7 \mathrm{~Hz})$ of the proton at the chloro-substituted carbon is due to couplings with both bridgehead hydrogens. The relative positions of methyl and phenyl were determined by NOE experiments: Irradiation at $\delta 3.45(1-\mathrm{H})$ enhanced the intensity of vinyl and phenyl resonances, while irradiation at the second bridgehead position ( $\delta 2.85$ ) yielded a NOE enhancement of the methyl and of a methylene signal. The stereochemistry at C-9 was deduced from a NOE enhancement of $9-\mathrm{H}$ (in addition to $1-\mathrm{H}$ and $\mathrm{CH}_{3}$ ) during irradiation of the phenyl resonance.

The minor component $12 \mathbf{b}$ was detected by a set of ${ }^{13} \mathrm{C}$ NMR resonances closely similar to those of $12 \mathrm{a}$. As expected for the exchange of phenyl and methyl, 1- $\mathrm{H}$ was shifted upfield $(-0.27 \mathrm{ppm})$ and $6-\mathrm{H}$ was shifted downfield $(+0.37 \mathrm{ppm})$ relative to $12 \mathbf{a}$.

When the enol ether 13 was added to a mixture of 10 and $\mathrm{ZnCl}_{2} / \mathrm{Et}_{2} \mathrm{O}$ in dichloromethane, $37 \%$ of the bicyclic compounds $15 \mathrm{a}-\mathrm{c}$ and 16 were obtained in addition to $40 \%$ of the aldehyde 14 , which has previously been prepared from 10 and 2-methyl-1-siloxypropene. ${ }^{15 b}$

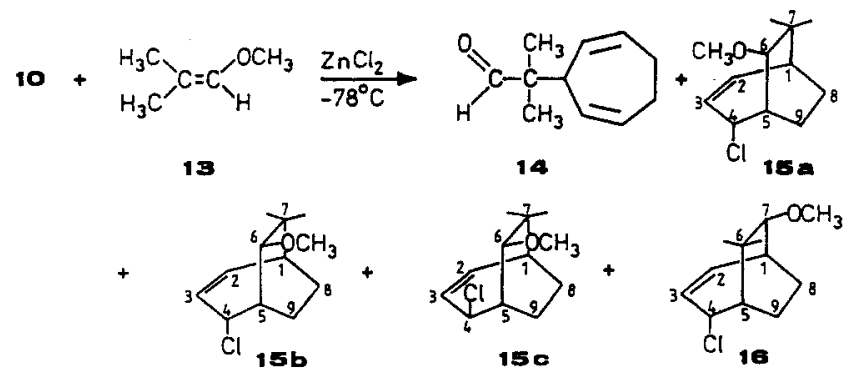

The similarity of the ${ }^{13} \mathrm{C}$ NMR chemical shifts of $15 \mathrm{a}-\mathrm{c}$ and 16 (Table I) indicates that all of these compounds incorporate the same bicyclic framework. The connectivity of the carbon atoms, i.e., the constitution of $15 \mathbf{a}-\mathbf{c}$, was 
Table II. ${ }^{1} \mathrm{H}$ NMR Chemical Shifts $\left(\mathrm{CDCl}_{8}\right)$ and $\mathrm{H}-\mathrm{H}$ Coupling Constants (Hz) of the Bicyclo[3.2.2]nonenes 15a-c and 16

\begin{tabular}{|c|c|c|c|c|}
\hline & $15 a$ & $15 b$ & $15 c$ & 16 \\
\hline $2-\mathrm{H}$ & $\begin{aligned} 5.86 \\
J_{2,3}=10.8 \\
J_{2,1}=8.9 \\
J_{2,4}=1.8\end{aligned}$ & $\begin{array}{c}6.02 \\
J_{2,3}=10.6 \\
J_{2,1}=9.5 \\
J_{2,4}=1.1\end{array}$ & $\begin{array}{c}5.93 \\
J_{2,3}=11.0 \\
J_{2,1}=9.3 \\
J_{2,4}=1.8\end{array}$ & $\begin{array}{c}5.93 \\
J_{2,3}=10.8 \\
J_{2,1}=9.3 \\
J_{2,4}=1.6\end{array}$ \\
\hline 3-H & $\begin{array}{c}5.61 \\
J_{3,2}=10.8 \\
J_{3,4}=2.8 \\
J_{3,5}=1.9 \\
J_{3,1}=0.6\end{array}$ & $\begin{aligned} 5.57 \\
J_{3,2}=10.6 \\
J_{3,4}=4.4 \\
J_{3,5}=1.5\end{aligned}$ & $\begin{array}{c}5.49 \\
J_{3,2}=11.0 \\
J_{3,4}=2.6 \\
J_{3,5}=1.9\end{array}$ & $\begin{aligned} 5.59 \\
J_{3,2}=10.8 \\
J_{3,4}=2.9 \\
J_{3,5}=1.6\end{aligned}$ \\
\hline $4-\mathrm{H}$ & $\begin{array}{l}5.12 \\
\mathrm{mc} \\
J_{4,5} \approx 3\end{array}$ & $\begin{array}{c}4.84 \\
J_{4,5}=5.5 \\
J_{4,3}=4.4\end{array}$ & $\begin{array}{c}4.73 \\
J_{4,3}=2.7 \\
J_{4,6}=2.7 \\
J_{4,9}=1.8\end{array}$ & $\begin{array}{c}5.14 \\
J_{4,5}=4.5 \\
J_{4,3}=2.9\end{array}$ \\
\hline $6-\mathrm{H}$ & $\begin{array}{c}3.18 \\
J_{6,5}=5.1\end{array}$ & $\begin{array}{c}2.91 \\
J_{6,5}=0.7 \\
J_{8,}=1.9\end{array}$ & $\begin{array}{c}3.34 \\
J_{6,6}=0.8 \\
J_{6}=1.5\end{array}$ & $\begin{array}{l}2.93(7-\mathrm{H}) \\
J_{7,1}=1.4 \\
J_{78}=1.4\end{array}$ \\
\hline $5-\mathrm{H}$ & $\begin{array}{c}2.55 \\
\mathrm{mc} \\
1.64-1.87\end{array}$ & $\begin{array}{c}2.33 \\
\mathrm{mc} \\
1.71-1.95\end{array}$ & $\begin{array}{c}2.28 \\
\mathrm{mc} \\
1.44-1.50\end{array}$ & $\begin{array}{c}2.32(1-\mathrm{H}) \\
\mathrm{mc} \\
1.57-1.86 \\
(5-\mathrm{H})\end{array}$ \\
\hline 8,9-H & $2.17-2.34$ & $2.08-2.19$ & $1.80-2.03$ & $1.99-2.09$ \\
\hline $10-\mathrm{H}$ & 0.91 & 1.02 & 1.00 & 1.08 \\
\hline $11-H$ & 1.13 & 1.05 & 0.96 & 1.05 \\
\hline $\mathrm{OCH}_{3}$ & 3.39 & 3.35 & 3.31 & 3.26 \\
\hline
\end{tabular}

derived from the ${ }^{13} \mathrm{C}-{ }^{13} \mathrm{C}$ coupling constants (Table I), which were obtained by one-dimensional INADEQUATE spectroscopy. Because of the similarity of the C-1-C-7 and the $\mathrm{C}-5-\mathrm{C}-6$ coupling constants in $15 \mathrm{c}$, the orientation of the 6,7-ethano bridge in this compound has been ascertained by two-dimensional INADEQUATE spectroscopy.

The isolated quantity of 16 was too small to obtain the ${ }^{13} \mathrm{C}-{ }^{13} \mathrm{C}$ coupling constants with high precision. Therefore, the constitution of this isomer was certified by a two-dimensional $\delta \delta\left({ }^{1} \mathrm{H}\right)$ correlated spectrum (COSY). Since one bridgehead hydrogen $(1-\mathrm{H})$ is coupled to the vinylic $2-\mathrm{H}$ and to $\mathrm{CHOCH}_{3}(7-\mathrm{H})$, the orientation of the 6,7-ethano bridge must be opposite as in $15 a-c$.

The configurations of $15 a-c$ and 16 were assigned on the basis of two-dimensional nuclear Overhauser effect spectroscopy (NOESY). Figure 1 shows a NOE between the $\mathrm{CHCl}(4-\mathrm{H})$ and the $\mathrm{CHOCH}_{3}(6-\mathrm{H})$ protons in $15 \mathrm{~b}$. Since a NOE is only possible, if $4-\mathrm{H}$ and $6-\mathrm{H}$ point toward each other, the relative configurations of both C- 4 and C-6 can thus be attributed. None of the other compounds showed a NOE between these protons.

In $15 \mathrm{c}$, one $\mathrm{CH}_{3}$ group $(\delta 0.96)$ shows a NOE with protons of the $\mathrm{C}_{2} \mathrm{H}_{4}$ bridge, and the other $\mathrm{CH}_{3}$ group ( $\delta 1.00$ ) shows a NOE with 6-H. These observations imply the $\mathrm{OCH}_{3}$ group being on the side of the $\mathrm{C}_{2} \mathrm{H}_{4}$ bridge. The position of $\mathrm{Cl}$ is derived from a NOE between $\mathrm{CHCl}$ and protons of the $\mathrm{C}_{2} \mathrm{H}_{4}$ bridge. Similar arguments allowed

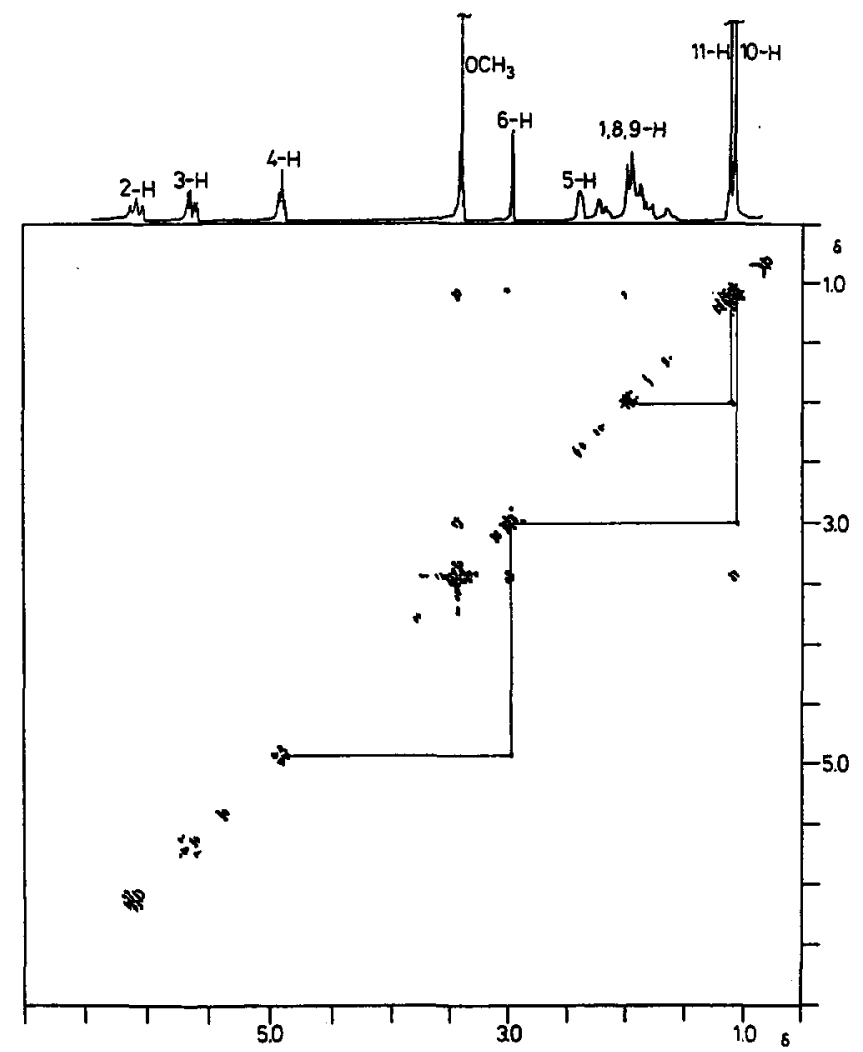

Figure 1. 200-MHz NOESY spectrum of $15 \mathbf{b}$ in $\mathrm{CDCl}_{3}$.

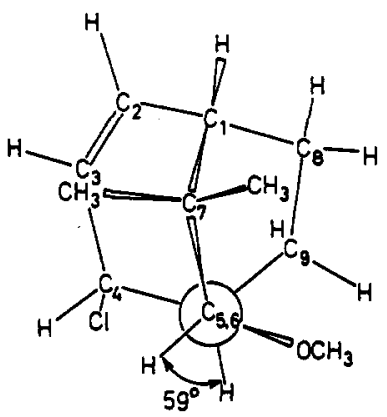

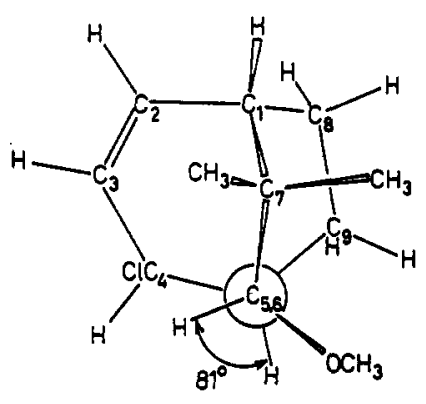

B

Figure 2. Calculated ${ }^{17}$ conformations $A$ and $B$ of the bicyclo[3.2.2]nonene $15 \mathrm{~b}$.

the stereochemical assignments of $15 \mathrm{a}$ and $\mathbf{1 6}$.

Conformations. Like the ${ }^{13} \mathrm{C}$ NMR chemical shifts, the ${ }^{1} \mathrm{H}$ NMR chemical shifts of corresponding nuclei are closely similar (Table II). There are considerable differences of corresponding $\mathrm{H}-\mathrm{H}$ coupling constants, however, which indicate unlike dihedral angles in the different isomers. The analysis is complicated by the fact that the bicyclononenes 15 and 16 may exist in two different conformations $A$ and $B$, depicted for compound $\mathbf{1 5 b}$ (Figure 2).

The energy differences of the various conformers, which have been calculated by a force-field method (MMPMI ${ }^{17}$ ),

Table III. Comparison of Calculated ${ }^{a}$ Dihedral Angles of Compounds 15a-c and 16 with the Corresponding H-H Coupling

${ }^{a}$ MMPMI: ref 17. ${ }^{b}$ For 16: $\theta(\mathrm{H}-1-7-\mathrm{H})$ and $J_{1,7}$. 
are very small (Table III), and the preferred conformations cannot be derived from the calculated $\Delta H_{f}{ }^{\circ}$ values. The 5,6 -coupling constants of $15 \mathrm{~b}, \mathrm{c}$ and 16 , however, allow us to assign these compounds to conformation B since the $J$ values of approximately $1 \mathrm{~Hz}$ are in accord with a dihedral angle of $\approx 80^{\circ}(\mathrm{B})$. Larger $J_{5,6}$ values would be expected for the dihedral angles of $56-59^{\circ}$ (conformation A) on the basis of the Karplus equation. ${ }^{18}$

The conformation of $15 \mathrm{a}$ cannot be assigned on the basis of $J_{5,6}$ as the observed value of $\approx 5 \mathrm{~Hz}$ fits the calculated dihedral angles of both conformers (Table III). The coupling constants $J_{3,4}=2.8 \mathrm{~Hz}$ and $J_{4,5} \approx 3 \mathrm{~Hz}$, however, are better consistent with dihedral angles of $71^{\circ}$ and $72^{\circ}$ (A) than with angles of $51^{\circ}$ and $55^{\circ}$ (conformation $\mathrm{B}$ ). Therefore, 15a appears to be the only isomer that prefers conformation A. This conclusion is in accord with the finding that $J_{3,4}$ and $J_{4,5}$ are considerably greater in $15 \mathrm{~b}$ than in $15 \mathrm{a}$, though the configuration of $\mathrm{C}-4$ is identical in both cases.

Discussion. Bicyclononadiene 12a, the major product of the reaction of 10 with 11 , is formed via [ $3+2]$-cycloaddition of the cycloheptadienyl cation 9 with 1-phenylpropyne (11). Probably, this cycloaddition proceeds stepwise, i.e., phenylpropyne 11 attacks position 1 of the cycloheptadienyl cation 9 to yield vinyl cation 17 as the intermediate. Successive cyclization generates the bridged cation 18 , which reacts stereoselectively at the backside with $\mathrm{Cl}^{-19}$ to form the secondary chloride 12a. The minor isomer $12 \mathrm{~b}$ can be rationalized by initial attack of 11 at $\mathrm{C}-3$ of the cycloheptadienyl cation 9. Analogous [3+ 2]-cycloaddition reactions of allyl cations with phenylpropyne (11) have previously been reported by Miller and Moore. ${ }^{20}$

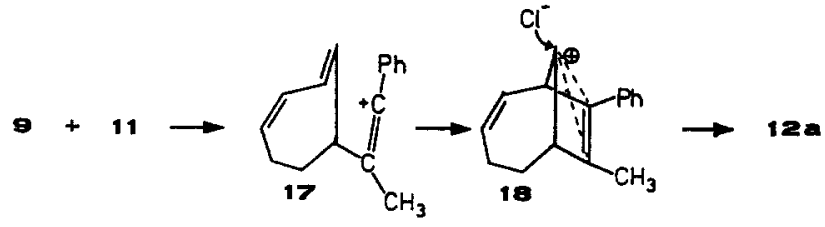

Products arising from [5+2]-cycloaddition of 9 with 11 have not been isolated, possibly because the eventually formed cycloadduct 19 would cyclize to yield the highly stabilized cation 20 . According to previous studies, ${ }^{21} 20$ is expected not to be intercepted by $\mathrm{Cl}^{-}$under these reaction conditions but to react with another $\pi$-system (e.g. $10,11,12)$, thus giving rise to the higher boiling products. ${ }^{21 \mathrm{c}}$

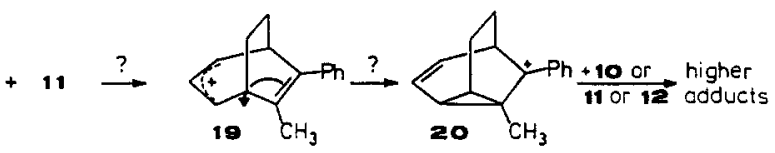

As described above, monocyclic and bicyclic products are formed in almost equal yield by the reaction of 10 with 13. If the enol ether 13 attacks $\mathrm{C}-3$ of the dienylic cation 9 , the methoxycarbenium ion 21 is produced, which hydrolyzes to give the aldehyde 14. Attack of the enol ether

(17) (a) Allinger, N. L. J. Am. Chem. Soc. 1977, 99, 8127. (b) Gajewgki J. J.; Gilbert, K. E. Molecular Mechanics Package (MS-DOS Computers); Serena Software: Bloomington, IN.

(18) (a) Karplus, M. J. Am. Chem. Soc. 1963, 85, 2870. (b) Günther, H. NMR-Spektroskopie; Thieme: Stuttgart, 1983; p 105

(19) (a) Diaz, A. F.; Fulcher, J.; Sakai, M.; Winstein, S. J. Am. Chem. Soc. 1974, 96, 1264. (b) Diaz, A.; Fulcher, J. J. Am. Chem. Soc. 1976, 98 , 798.

(20) Miller, A.; Moore, M. Tetrahedron Lett. 1980, 577.

(21) (a) Mayr, H. Angew. Chem. 1981, 93, 202. Angew. Chem., Int. Ed. Engl. 1981, 20, 184. (b) Mayr, H.; Striepe, W. J. Org. Chem. 1983, 48, 1159. (c) Mayr, H.; Wilhelm, E.; Kaliba, C. J. Chem. Soc., Chem. Commun. 1981, 683 . at $\mathrm{C}-1$ of the cycloheptadienyl cation 9 yields cation $\mathbf{2 2}$, which can cyclize to the stereoisomeric cations 23 and 24 . The formation of $15 \mathrm{~b}$ and $15 \mathrm{c}$ indicates that $\mathrm{Cl}^{-}$can approach to C-4 of the allyl cation 23 from top and bottom. Topside attack at C-2 of 23 is obviously shielded by one of the geminal methyl groups since only one stereoisomer 16 has been detected. The formation of oxonium ion 25 from 24 and selective backside attack at C-4 may be responsible for the formation of $\mathbf{1 5 a}$ as the only isomer with the methoxy group pointing toward the propeno bridge.

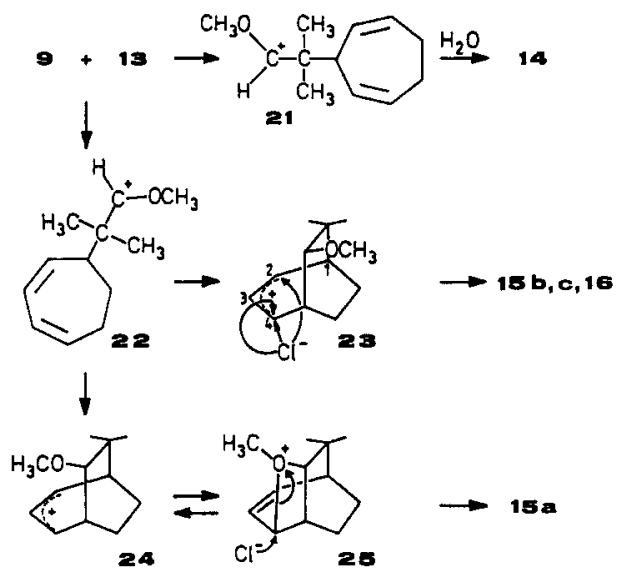

Since 22 has not been trapped by external nucleophiles, the formation of 23 and 24 via concerted [5 + 2]-cycloaddition cannot be excluded. When the cycloheptadienyl cation 9 was reacted with isobutene ${ }^{15 a}$ or silyl enol ethers, ${ }^{15 b}$ products derived from 1- and 3-attack were obtained, i.e., the activation energies of 1- and 3-attack are usually of similar magnitude. It is unlikely, therefore, that in this case a concerted cycloaddition mechanism is alone responsible for the formation of the bicyclic products. If the concerted [5+2]-cycloaddition mechanism had a significant preference over the stepwise process, 14 would not be formed along with 15 and 16 . We, therefore, suggest 23 and 24 to be formed via a stepwise process, which allows us to treat all presently known dienyl cation-alkene reactions on the basis of a single mechanistic concept.

\section{Experimental Section}

General. NMR spectra were recorded on a Varian XL 200 spectrometer. Mass spectra were recorded on a VG 70-250 spectrometer.

The 1D-INADEQUATE spectra were measured in 0.4-0.8 M $\mathrm{CDCl}_{3}$ solutions by using the pulse sequence $90^{\circ}-\tau-180^{\circ}-\tau-$ $90^{\circ}-\Delta-90^{\circ}-\mathrm{FID}\left(t_{2}\right)^{22}$ with $\tau=6.67 \times 10^{-3} \mathrm{~s}$ and $t_{2}=10 \mathrm{~s}$. For a spectral width of $6230 \mathrm{~Hz}$ a digital resolution of $0.2 \mathrm{~Hz}$ was obtained with 32000 data points. The 2D-INADEQUATE spectrum of $15 \mathrm{c}$ was recorded at $298 \mathrm{~K}$ in a $0.7 \mathrm{M} \mathrm{CDCl}_{3}$ solution in the presence of $\mathrm{Cr}(\mathrm{acac})_{3}$ by using the pulse sequence $90^{\circ}-\tau-$ $180^{\circ}-\tau-90^{\circ}-t_{1} / 2-135^{\circ}-\mathrm{FID}\left(t_{2}\right)^{23}$ with $t_{2}=2.84 \mathrm{~s}$ (based on the maximal value of $t_{1}=0.75 \mathrm{~s}$ ) and $\tau=6.75 \times 10^{-3} \mathrm{~s}$. Spectral width was $6230 \mathrm{~Hz}$. Two hundred fifty-six FIDs on $2 \mathrm{~K}$ data points were taken, and 288 scans were accumulated for each FID resulting in a total acquisition time of $62 \mathrm{~h}$. After a Gaussian multiplication in both dimensions, the FID was transformed. The measured DBQs were in good agreement with the calculated ones.

The COSY spectra were measured by using the pulse sequence $90^{\circ}-t_{1}-90^{\circ}-\Delta-90^{\circ}-\mathrm{FID}\left(t_{2}\right)$ with double quantum filtering. ${ }^{24}$ Two hundred fifty-six FIDs on 512 data points were recorded, and each FID was obtained from 32 scans. The FIDs were multiplied with a pseudo Gaussian function and zero filled in $F_{1}$. The FID was then transformed and symmetrized. The spectral width for 15a,b

(22) Bax, A.; Freeman, R.; Kempsell, S. P. J. Am. Chem. Soc. 1980, 102,4849 .

(23) Mareci, T. H.; Freeman, R. J. Magn. Reson. 1982, 48, 158.

(24) Bax, A.; Freeman, R.; Morris, G. A. J. Magn. Reson. 1981, 42, 169. 
and 16 was $F_{1}=F_{2}=1300 \mathrm{~Hz}$, and $F_{1}=F_{2}=1208.5 \mathrm{~Hz}$ for $15 \mathrm{c}$. With a recycle delay $t_{2}=4.5 \mathrm{~s}$ and $\Delta=1 \times 10^{-5} \mathrm{~s}$ the acquisition time was $10 \mathrm{~h}$ in each case. Phase cycling for quadrature detection in both dimensions was used.

The NOESY spectra were recorded by using the pulse sequence $90^{\circ}-t_{1}-90^{\circ}-\tau_{\mathrm{m}}-90^{\circ}-\mathrm{FID}\left(t_{2}\right)$ with $\tau_{\mathrm{m}}=\tau_{\mathrm{m}}+t_{1} \kappa^{25}$ The mixing times were $\tau_{\mathrm{m}}=2.7 \mathrm{~s}(15 \mathrm{a}), 2.5 \mathrm{~s}(15 \mathrm{~b}), 3.8 \mathrm{~s}(15 \mathrm{c})$, and $1.85 \mathrm{~s}$ (16), and $\kappa$ was 0.15 . The values of the other parameters were equivalent to those used in the measurements of the COSY spectra.

5-Chloro-1,3-cycloheptadiene (10) was prepared from cycloheptatriene and $\mathrm{HCl}$ as described previously. ${ }^{15 \mathrm{~b}}$ The sample used in the following reactions was contaminated by some 6-chloro1,3-cycloheptadiene, which is inert under these conditions. ${ }^{15 b}$ Zinc chloride/ether was prepared according to ref 26 .

5-Chloro-1,3-cycloheptadiene (10) and 1-Phenylpropyne (11). A solution of $11(2.32 \mathrm{~g}, 20.0 \mathrm{mmol})$ in $\mathrm{CH}_{2} \mathrm{Cl}_{2}(30 \mathrm{~mL})$ was added dropwise $(1.5 \mathrm{~h})$ to a cooled solution $\left(-78^{\circ} \mathrm{C}\right)$ of $10(2.06$ g, $16.0 \mathrm{mmol})$ and $\mathrm{ZnCl}_{2}(3.22 \mathrm{~g}) / \mathrm{Et}_{2} \mathrm{O}(2.7 \mathrm{~mL})$ in $35 \mathrm{~mL}$ of $\mathrm{CH}_{2} \mathrm{Cl}_{2}$. After stirring at $-78^{\circ} \mathrm{C}$ for $4.5 \mathrm{~h}$, the solution was washed with $25 \%$ aqueous $\mathrm{NH}_{4} \mathrm{Cl}$ solution and dried over $\mathrm{CaCl}_{2}$, and the solvent was evaporated. Distillation gave a forerun of unreacted 11 and $1.65 \mathrm{~g}(42 \%)$ of $12 \mathrm{a}$ and $12 \mathrm{~b}(\approx 10: 1$ estimated from the NMR signals of the bridgehead protons) with bp $100-105^{\circ} \mathrm{C}$ (bath) $(0.1 \mathrm{mbar})$ and $2.10 \mathrm{~g}$ of nonvolatile residue.

$\left(1 R^{*}, 9 S^{*}\right)$-9-Chloro-7-methyl-8-phenylbicyclo[4.2.1]nona2,7-diene (12a): ${ }^{1} \mathrm{H}$ NMR $\left(\mathrm{CDCl}_{3}\right) \delta$ 1.79-1.91 (m, $\left.1 \mathrm{H}, 5-\mathrm{H}\right), 1.93$ (mc, $\left.3 \mathrm{H}, \mathrm{CH}_{3}\right), 2.03-2.32\left(\mathrm{~m}, 3 \mathrm{H}, 4-\mathrm{H}_{2}, 5-\mathrm{H}\right), 2.85$ (br t, $J=6.7$ $\mathrm{Hz}, 1 \mathrm{H}, 6-\mathrm{H}$ ), 3.45 (br t, $J=6.7 \mathrm{~Hz}, 1 \mathrm{H}, 1-\mathrm{H}$ ), 4.65 (br t, $J=$ $6.7 \mathrm{~Hz}, 1 \mathrm{H}, 9-\mathrm{H}), 5.65-5.77(\mathrm{~m}, 1 \mathrm{H}, 2-\mathrm{H}), 5.86-5.98(\mathrm{~m}, 1 \mathrm{H}, 3-\mathrm{H})$, $7.31(\mathrm{mc}, 5 \mathrm{H}) ;{ }^{13} \mathrm{C} \mathrm{NMR}\left(\mathrm{CDCl}_{3}\right) \delta 13.50\left(\mathrm{q}, \mathrm{CH}_{3}\right), 25.21,26.79$ (2 t, C-4,5), 52.62, 52.99 (2 d, C-1,6), 62.44 (d, C-9), 126.74 (d, C-para), 127.89, 128.14 (2d, C-ortho, meta), 128.20, 133.33 (2 d, C-2,3), 136.48, 136.75, 136.89 (3 s, C-7,8, C-ipso). Anal. Calcd for $\mathrm{C}_{16} \mathrm{H}_{17} \mathrm{Cl}(244.8)$ : C, 78.51; H, 7.00. Found: $\mathrm{C}, 78.37 ; \mathrm{H}, 7.08$.

(25) Kumar, A.; Ernst, R. R.; Wüthrich, K. Biochem. Biophys. Res. Commun. 1980, 95, 1.

(26) Mayr, H.; Striepe, W. J. Org. Chem. 1985, 50, 2995.
9-Chloro-8-methyl-7-phenylbicyclo[4.2.1]nona-2,7-diene (12b) is assumed to be the minor component of the mixture because of ${ }^{1} \mathrm{H}$ NMR absorptions at $\delta 3.12-3.27(\mathrm{~m}, 1,6-\mathrm{H})$ and $4.70(\mathrm{br} \mathrm{t}, J=6.7 \mathrm{~Hz}, 9-\mathrm{H})$. The relation of these protons was ascertained by spin-decoupling experiments. ${ }^{13} \mathrm{C} \mathrm{NMR}\left(\mathrm{CDCl}_{3}\right)$ $\delta 15.01$ (q, $\mathrm{CH}_{3}$ ), 25.45, 27.14 (2 t, C-4,5), 51.55, 54.60 (2 d, C-1,6), 62.52 (d, C-9), 126.89 (d, C-para), 128.00, 128.31 (2d, C-ortho, meta), 127.34, 133.93 (2 d, C-2,3), 133.26, 135.76, 136.79 (3 s, C-7,8, C-ipso).

5-Chloro-1,3-cycloheptadiene (10) and 1-Methoxy-2methylpropene (13). A solution of $13(4.30 \mathrm{~g}, 50.0 \mathrm{mmol})$ in 30 $\mathrm{mL}$ of $\mathrm{CH}_{2} \mathrm{Cl}_{2}$ was added dropwise $(0.5 \mathrm{~h})$ to a rapidly stirred solution of $10(5.14 \mathrm{~g}, 40.0 \mathrm{mmol})$ and $\mathrm{ZnCl}_{2}(5.04 \mathrm{~g}) / \mathrm{Et}_{2} \mathrm{O}(4.20$ $\mathrm{mL})$ in $60 \mathrm{~mL}$ of $\mathrm{CH}_{2} \mathrm{Cl}_{2}\left(-78^{\circ} \mathrm{C}\right)$. After $1 \mathrm{~h}$ the reaction mixture was washed with $50 \mathrm{~mL}$ of $25 \%$ aqueous $\mathrm{NH}_{4} \mathrm{Cl}$ solution and dried with $\mathrm{CaCl}_{2}$. The solvent was evaporated, and the yellow residue was distilled to give $1.29 \mathrm{~g}$ of 10 (bp $20-30^{\circ} \mathrm{C}$ (bath) $(0.4 \mathrm{mbar})$ ), $5.09 \mathrm{~g}$ of the 1:1 products $14-16$, and $1.27 \mathrm{~g}$ of a nonvolatile residue. Separation of $1.00 \mathrm{~g}$ of the $1: 1$ product mixture by MPLC (silica gel, $15-25 \mu \mathrm{m}$, hexane:ether $=98.5: 1.5$ ) yielded $153 \mathrm{mg}$ of (1S*,4R*,6S*)-4-chloro-6-methoxy-7,7-dimethylbicyclo[3.2.2]non-2-ene (15a), $81 \mathrm{mg}$ of $\left(1 S^{*}, 4 R^{*}, 6 R^{*}\right)$-4-chloro-6-methoxy7,7-dimethylbicyclo[3.2.2] non-2-ene (15b), $189 \mathrm{mg}$ of (1 $\left.S^{*}, 4 S^{*}, 6 R^{*}\right)$-4-chloro-6-methoxy-7,7-dimethylbicyclo[3.2.2]non-2-ene (15c), $54 \mathrm{mg}$ of $\left(1 S^{*}, 4 R^{*}, 7 S^{*}\right)$-4-chloro-7-methoxy6,6-dimethylbicyclo[3.2.2] non-2-ene (16), and $393 \mathrm{mg}$ of $2-(2,6-$ cycloheptadienyl)-2-methylpropanal (14) (77\% total yield with respect to reacted 10 ).

NMR data: Tables I and II. Mass spectrum (70 eV) of 15c: $\mathrm{m} / z$ (rel intensity) $216,214\left(0.5 \%, 1.9 \%, \mathrm{M}^{+}\right), 147(3), 135(2)$, 121 (3), 105 (4), 97 (12), 93 (15), 91 (11), 86 (100). Anal. Calcd for $\mathrm{C}_{12} \mathrm{H}_{19} \mathrm{ClO}$ (214.7): C, 67.12; H, 8.92. Found for 15a: C, 67.56; $\mathrm{H}, 9.31$. Found for $15 \mathrm{~b}$ : C, 67.89; H, 8.97. Found for $15 \mathrm{c}: \mathrm{C}$, $67.02 ; \mathrm{H}, 8.78$. Spectroscopic data of 14 : see ref $15 \mathrm{~b}$.

Acknowledgment. We thank R. Lammers for experimental assistance, Dr. E. Bäuml and Dr. Ch. Wolff for discussions, and the Deutsche Forschungsgemeinschaft and the Fonds der Chemischen Industrie for financial support.

\title{
Photocycloaddition of 1,4-Dioxene to 3-Methylcyclohex-2-en-1-one: Conformational Analysis, X-ray Crystal Structures, and Acid-Catalyzed Rearrangement of the Photoadducts
}

\author{
Jean-Marie Bernassau, Anne Bouillot, Marcel Fétizon,* Issam Hanna, and Elaine Rose Maia \\ Laboratoire de Synthèse Organique, Ecole Polytechnique, 91128 Palaiseau, Cedex, France \\ Thierry Prangé \\ L.U.R.E., Universitê de Paris-Sud, Bâtiment 209 D, 91405 Orsay, Cedex, France
}

Received October 15, 1986

\begin{abstract}
Photochemical cycloaddition of 1,4-dioxene to 3-methylcyclohex-2-en-1-one leads to a mixture of four 11methyl-1,4-dioxatricyclo[6.4.0.0. ${ }^{6.11}$ ]dodecan-7-one isomers 3-6. Their structures have been established by X-ray diffraction and ${ }^{13} \mathrm{C} N M R$, and their conformational properties have been studied by force field calculations. They only differ by the stereochemistry of the cyclobutane-dioxane junction, which is found to have a pronounced influence upon the conformation of the molecules. The four-membered rings are strongly distorted in all cases. These cyclobutane photoadducts undergo an unusual acid-catalyzed rearrangement, affording compounds 19-21. The structures of two of them, 19 and 20, have been established by X-ray diffraction. The formation of these rearranged products can be rationalized in terms of a common cationic intermediate 23 stabilized by oxygens.
\end{abstract}

The photocycloaddition of cyclic $\alpha, \beta$-unsaturated ketones to alkenes has been extensively studied. It has become an important tool in the arsenal of the synthetic organic chemist, leading to versatile intermediates that can be subsequently used in a number of ways. For example, the cyclobutane intermediates smoothly undergo an acidcatalyzed rearrangement, providing useful precursors of many natural products. ${ }^{1}$ 